\title{
DIAMOND DISCOVERY IN THE SLAVE CRATON: COMPILATIONS OF EXPLORATION DATA AS TOOLS FOR FUTURE DISCOVERY
}

\author{
John P. Armstrong \\ C.S. Lord Northern Geoscience Centre, Yellowknife, Canada
}

\section{INTRODUCTION}

Prompted by the discovery of a diamondiferous kimberlite at Point Lake in 1991, the area underlain by the Slave Craton in northern Canada has seen an incredible, sustained burst in exploration for kimberlites. To date over 350 kimberlites have been discovered in the region underlain by the Slave Craton. A portion of the data generated by the exploration efforts on the Slave Craton has been filed with the Department of Indian Affairs and Northern Development as assessment work to keep mineral claims in good standing. Much of the data filed on claims staked for kimberlite exploration has consisted of till sampling and kimberlite indicator mineral picking results, electron microprobe analyses of indicator minerals, airborne magnetic and electromagnetic surveys, and diamond drilling. These results are housed for public access in over 200 assessment filings. The vast majority of this data existed in paper form and a series of methods were employed to convert it to spatially related digital data.

Since 1999, a concerted effort has been made to create digital databases of kimberlite and diamond indicator sample locations, picking results, mineral chemistry data, total field magnetic images, and diamond drill logs contained within the publicly available Assessment Reports.

\section{DISCUSSION}

\section{Kimberlite Indicator and Diamond Database (KIDD)}

The Kimberlite Indicator and Diamond Database (Armstrong and Chatman, 2001) houses over 135000 till sample locations (Figure 1) with kimberlite indicator mineral (KIM) visual picking results. The KIDD compilation represents a work-in-progress and does not contain all the public data collected by exploration companies. Kimberlite clusters and fields shed particular suites of indicators and the indicator trains display variable features (Figure 2; Armstrong, 2003). Each particular kimberlite field is identifiable by
KIM till anomalies that are resolvable on the scale of the Slave Craton. Collectively, indicator dispersal trains sourced from each particular field may have down ice extents approaching a hundred kilometres and overall widths of 20 to 50 kilometres. On an individual basis most indicator trains have a pencil rather than a fan shaped dispersion, with length to width ratios typical of 8:1, although trains in the southeastern Slave may have aspect ratios of 23:1. The influence of ice speed, temperature and original bedrock topography in determining the pencil shaped nature of Slave KIM dispersals is unresolved. This impacts on the spacing of regional sampling as some trains have widths of $<1.5$ kilometres. The younger and prolific Lac de Gras field hosts volumetrically significant 'volcaniclastic to reworked volcaniclastic' kimberlite that has shed prodigious quantities of indicator minerals. The older kimberlite fields (as defined by Heaman et al., in press) are dominated by hypabyssal to diatreme facies kimberlite and are characterized by lower overall abundances of indicators (Armstrong, 2003).

\section{Kimberlite Indicator Mineral Chemistry Database (KIMC)}

The Kimberlite Indicator Mineral Chemistry Database (Armstrong, 2001) houses $>110000$ spatially located electron microprobe analyses of KIM's (Figure 1). Although electron microprobe data compiled to-date is concentrated in the Lac de Gras region data from other areas of the Slave craton also contain indicator minerals of high interest. KIMC extracts for garnet, chromite, clinopyroxene, and ilmenite are represented in Figure 3. The body of mineral chemical analyses may be used in focusing exploration and, in part, for elucidating the nature of the lithosphere beneath the Slave (ie. Grutter et al, 2001, Grutter, 2003 in press).

\section{Kimberlite Anomaly Drillhole Database (KANDD)}

The Kimberlite Anomaly Drillhole database (Armstrong and Preston, 2001) contains the locations and drill logs for approximately 1600 diamond drillholes that were drilled to test specific anomalies for the presence or absence of kimberlite (Figure 4). KANDD houses over 550 drill logs with kimberlite 
intersections. Information captured in the logs includes, overburden thickness, lake depth, field observation on the texture and mineralogy of the kimberlite, details on the nature of the contact with country rock, distribution of indicators and in some instances microdiamond counts. For a number of pipes drill logs from delineation drilling programs would enable users to model the pipe morphology and internal geology.

\section{Slave Magnetic Compilation (SMAC)}

The Slave Magnetic Compilation (Armstrong and Kenny, 2001; Figure 5) is a total field magnetic image collection. High resolution, detailed, <250metre line spacing airborne geophysical survey maps were scanned and geo-referenced and if available digital data was re-processed to create image files. Images are available for a significant portion of the Slave craton enabling users to compile the distribution of mafic dyke sets and bedrock discontinuities. The magnetic response of individual kimberlite intrusions is also captured by SMAC.

\section{SUMMARY}

The discovery of, and exploration for, diamondiferous kimberlites within the Slave Geological Province has resulted in the private sector generation of an immense volume of geological information and exploration data, some of which has been filed with government departments. Initial efforts to digitize the publicly available portion of this data resulted in a series of compilations with a variety of applications. The scope and magnitude of the data available is likely unsurpassed outside of privately held datasets.

\section{REFERENCES}

Armstrong, J.P., Chatman, J., 2001 Kimberlite Indicator and Diamond Database (KIDD): UPDATE: A compilation of publicly available till sample locations and kimberlite indicator mineral picking results, Slave Craton and environs, Northwest Territories and Nunavut, Canada. DIAND NWT Geology Division, Open Report 2001-01

Armstrong, J.P., Kenny, G. 2001. Slave Magnetics Compilation (SMAC). A digital image compilation of publically available total field magnetics data as filed under the Canada Mining Regulations: Northwest Territories and Nunavut, Canada. DIAND NWT Geology Division, EGS Open Report 2001-003.

Armstrong, J.P., 2001. A preliminary digital compilation of kimberlite indicator mineral chemistry (KIMC) extracted from publically available archived assessment filings, Slave Craton and environs, Northwest Territories and Nunavut, Canada. DIAND NWT Geology Division, DIAND EGS Open Report 2001-01.

Armstrong, J.P., 2003. Regional distribution and chemistry of kimberlite indicator minerals: Slave Craton. Extended Abstracts Indicator mineral methods in mineral exploration. Short Course Notes, Prospectors and Developers Association of Canada. March 2003.

Heaman L.M., Kjarsgaard B.K., Creaser R.A. 2003. The Timing of Kimberlite Magmatism in North America: Implications for Global Kimberlite Genesis and Diamond Exploration. Lithos in press

Grutter, H.S., Apter, D.B., Kong, J. 1999. Crust-mantle coupling: Evidence from mantle-derived xenocrystic garnets. Proceedings of the VIIth International Kimberlite Conference, J.B. Dawson Volume, pg 307313.

Grutter, H.S. 2003. Advanced indicator mineral chemistry techniques in diamond exploration. Indicator mineral methods in mineral exploration, Short Course Notes, Prospectors and Developers Association of Canada. March 2003.

Contact: JP Armstrong, PO Box 1500 Yellowknife, NWT, Canada, X1A 2R3, E-mail: john_armstrong@gov.nt.ca 


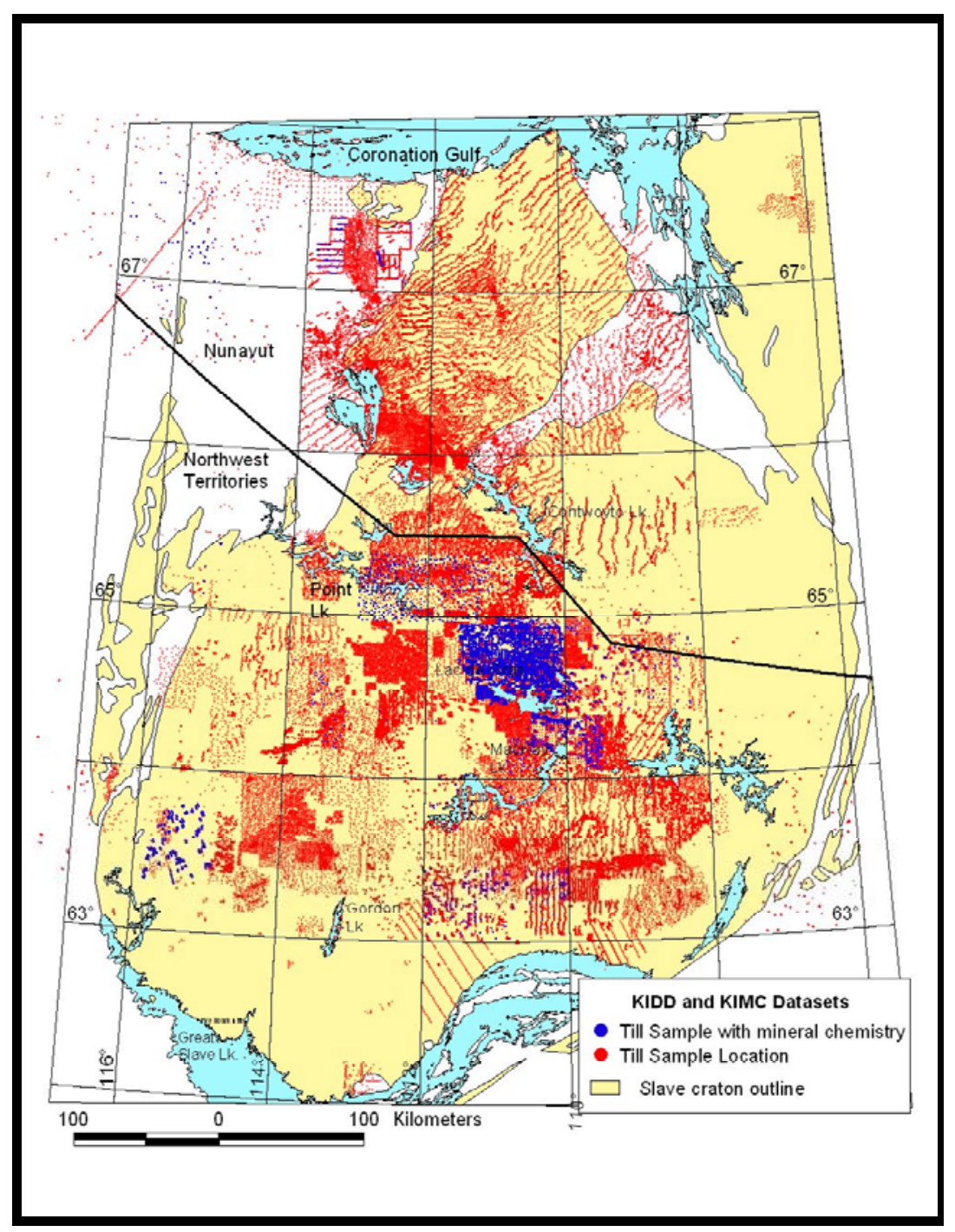

Figure 1. Distribution of KIDD and KIMC till samples, Slave Craton

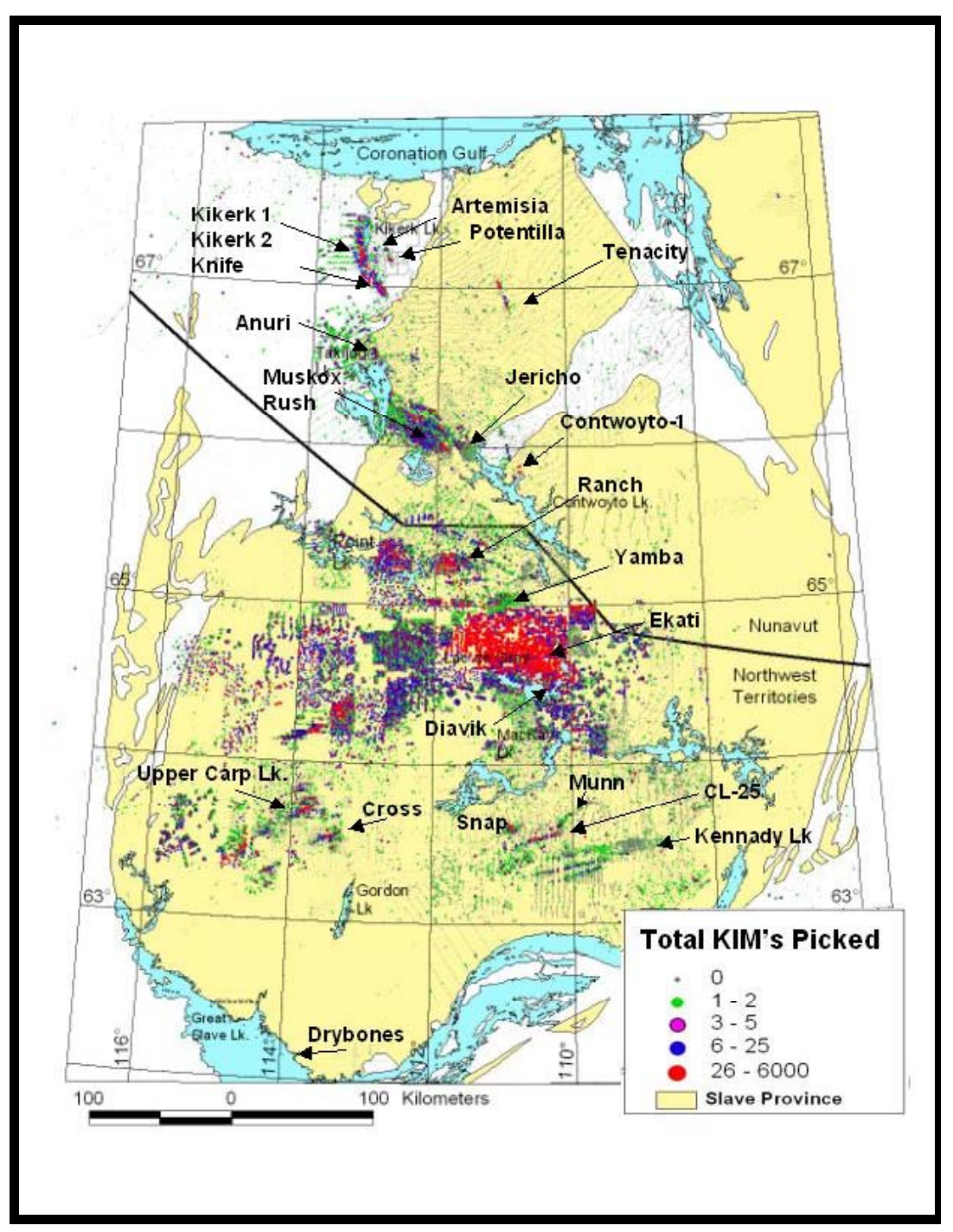

Figure 2. Significant kimberlites and anomalous till samples, Slave Craton 

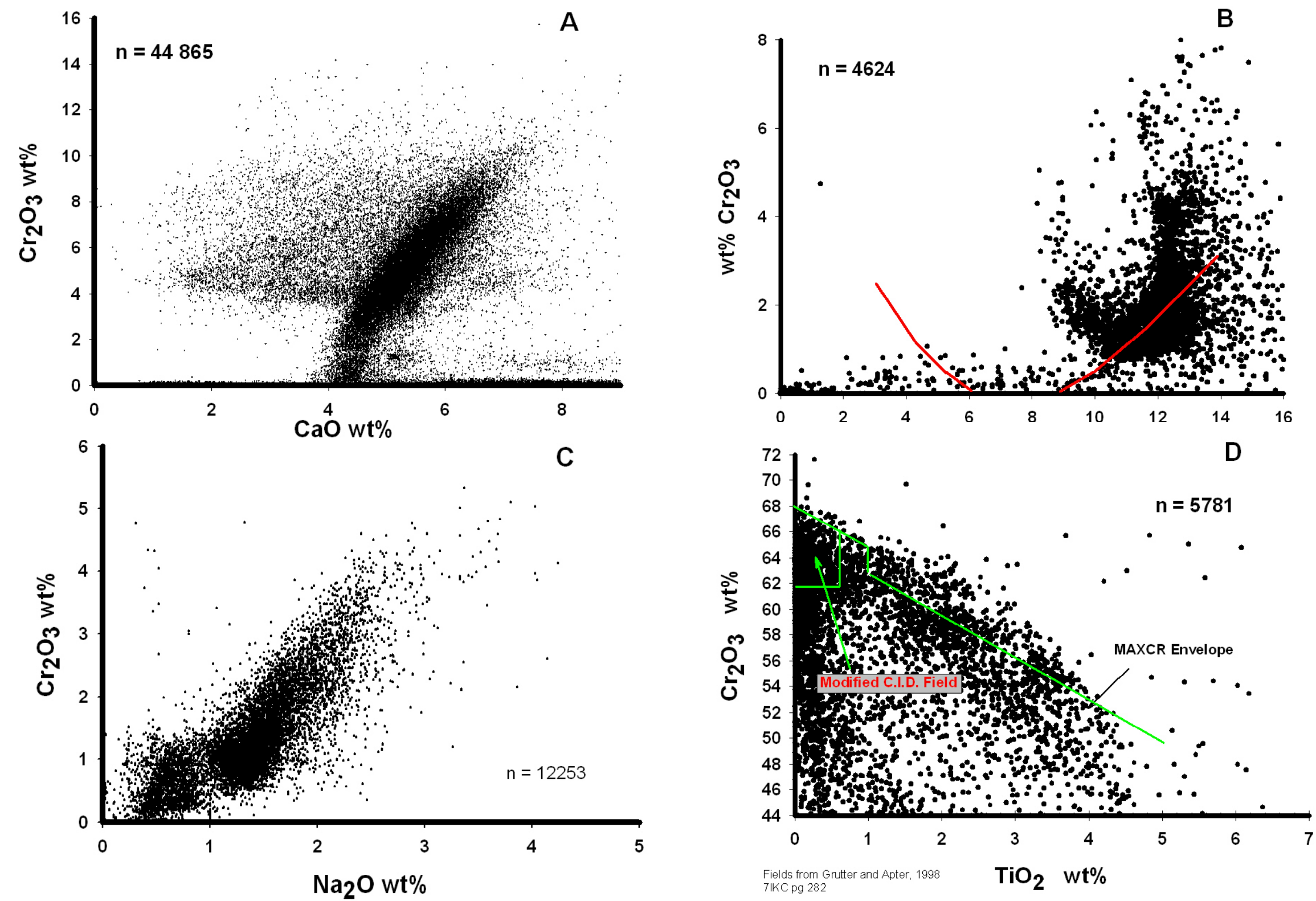

Figure 3. Selected A) garnet ; B) ilmenite; C) clinopyroxene; and D) spinel analyses for the slave craton extracted from the KIMC data. 


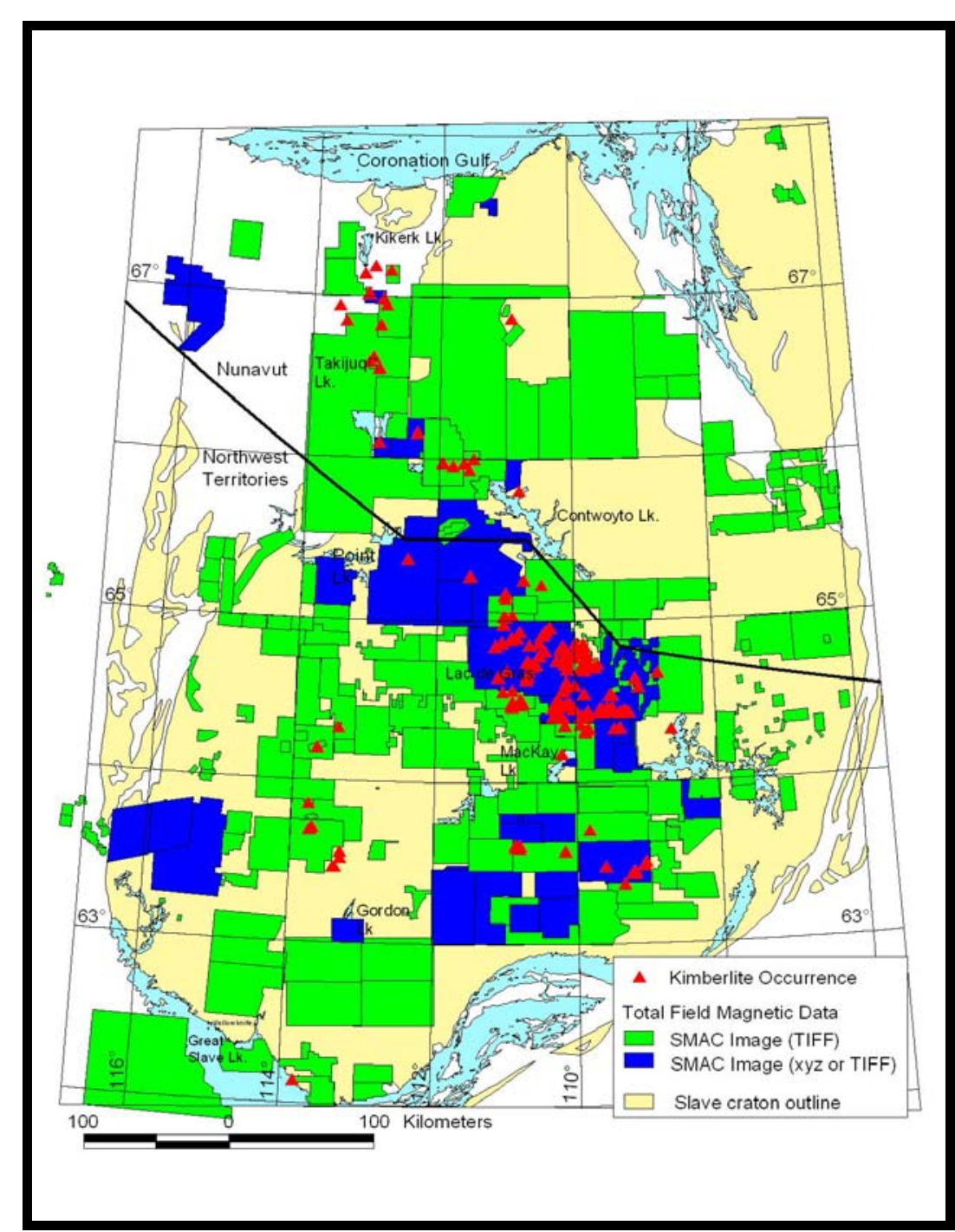

Figure 4. Slave Magnetic Compilation coverage.

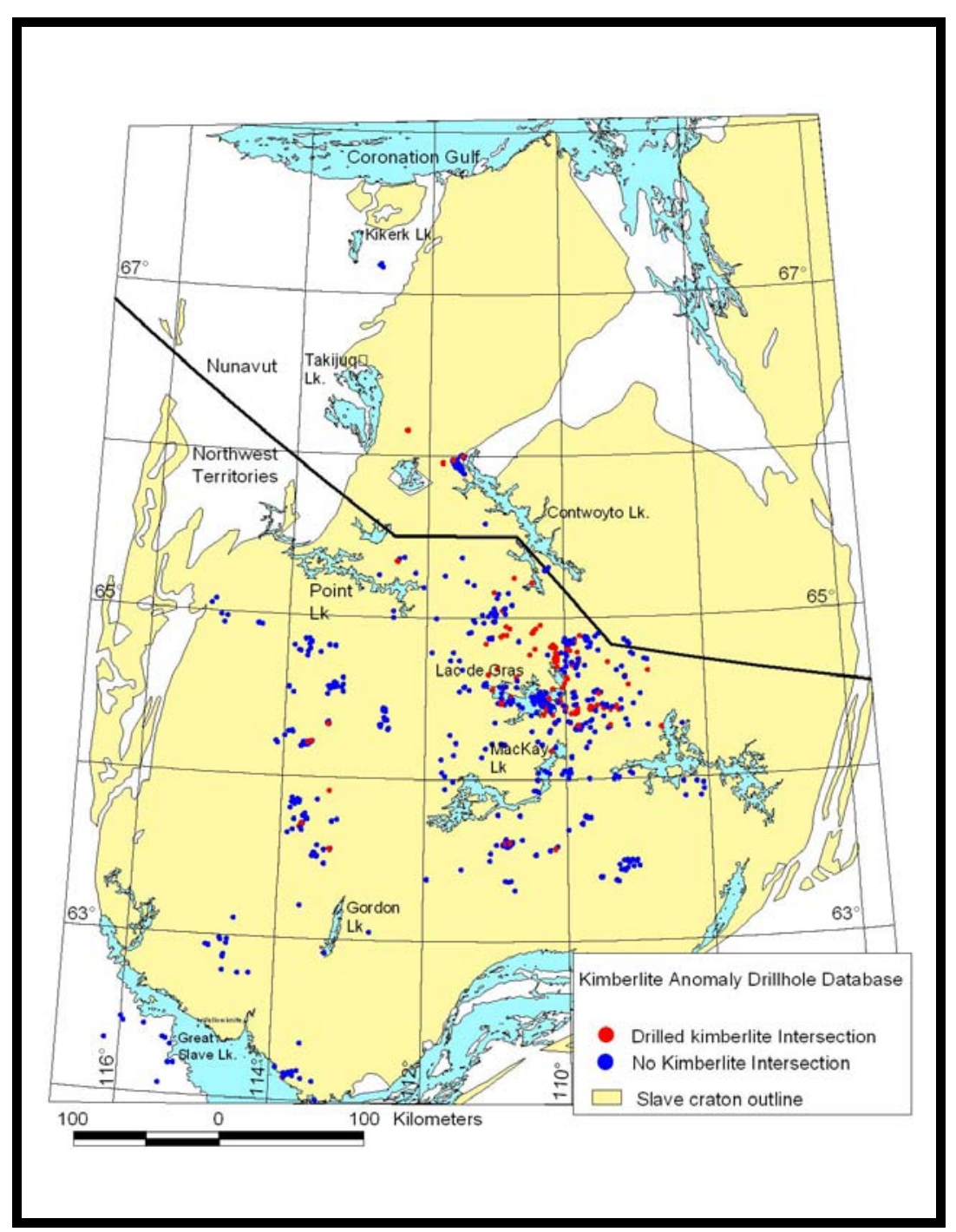

Figure 5. Distribution of drill holes extracted from KANDD data. 